\title{
Meningkatkan Hasil Belajar dengan Pendekatan Contextual Teaching and Learning (CTL) Mata Pelajaran PKn pada Siswa Kelas V SD Negeri 1 Jereweh
}

\author{
Muhammad Saleh, S.Pd.SD \\ SDN 1 Jereweh Kecamatan Jereweh \\ Email: muh.saleh11@gmail.com
}

\begin{abstract}
Abstrak: Penelitian ini bertujuan untuk meningkatkan hasil belajar siswa kelas V SDN 1 Jereweh pada mata pelajaran PKn dengan pendekatan Contextual Teaching and Learning (CTL) .

Penelitian in merupakan penelitian tindakan kelas. Subjek penelitian ini adalah kelas V SDN 1 Jereweh dengan jumlah siswa 26 orang. Penelitian ini berlangsung dalam tiga siklus dan masingmasing terdiri dari 4 tahapan yaitu perencanaan, kegiatan dan pengamatan, repleksi dan revisi pelaksanaan . Teknik pengumpulan data dalam penelitian ini adalah observasi dan tes formatif.

Hasil penelitian tindakan kelas dengan menerapkan pendekatan Contextual Teaching and Learning (CTL) menunjukkan bahwa hasil belajar PKn siswa mengalami peningkatan. Hal tersebut ditunjukkan dengan peningkatan nilai rata kelas yaitu pada saat siklus 1 persentase ketuntasan 34,61\% pada siklus 2 persentase ketuntasan $69,23 \%$, dan pada siklus 3 persentase ketuntasan $100 \%$, sedangkan ketuntasan maksimal yang tuntas meningkat 34,62 \% dari siklus 1 ke siklus 2, dan dari siklus 2 ke siklus 3 sebanyak 30,77 \%.
\end{abstract}

Kata Kunci: Hasil Belajar PKn, Pendekatan Contextual Teaching and Learning (CTL)

\section{Pendahuluan}

Pendidikan Kewarganegaraan (PKn) merupakan mata pelajaran yang wajib di pelajari dari jenjang pendidikan dasar yang berhubungan dengan budi pekerti yang tidak lepas dari kehidupan sehari-hari. Hal tersebut tercantum pada Undang-undang No. 20 pasal 37 ayat 1, yaitu menyatakan bahwa kurikulum pendidikan dasar dan menengah wajib memuat pendidikan agama, pendidikan kewarganegaraan, bahasa, matematika, ilmu pengetahuan alam, ilmu pengetahuan social, seni dan budaya, pendidikan jasmani dan olahraga, keterampilan/kejuruan, dan muatan lokal.

Meskipun pelajaran PKn mempunyai kemudahan dalam mempelajarinya karena membahas tentang moral dan budi pekerti dan kehidupan sehari-hari, namun masih ada beberapa siswa yang kurang 
mempunyai motivasi belajar untuk mempelajarinya sehingga menyebabkan hasil belajarnya turun, karena pelajaran PKn banyak mengandung perilaku.. Hal tersebut juga ditemukan di SDN 1 Jereweh khususnya kelas 5. Proses pembelajaran yang masih dominan pembelajaran satu arah terlihat dari masih sedikitnya interaksi baik yang terjadi antara guru dengan murid, murid dengan murid, dan kurang mandirinya siswa untuk menyelesaikan permasalahan-permasalahan setiap materi pembelajaran. Berdasarkan hal tersebut dapat disimpulkan bahwa, aktivitas siswa dalam mengikuti kegiatan belajar mengajar masih rendah, ini ditunjukkan dengan sedikitnya jumlah siswa yang mengajukan pendapat dalam menyelesaikan permasalahan yang diajukan oleh guru, dan menunjukkan ketidatertarikan siswa-siswa tersebut untuk belajar.

Pendekatan Contextual Teaching And Learning memungkinkan siswa menggunakan atau mengkaitkan pengetahuan dan ketrampilan akademik yang dimiliki untuk memecahkan masalah dunia nyata atau masalah kehidupan sehari-hari yang dialami yang lebih menekankan pada berfikir tingkat tinggi, transfer pengetahuan lintas disiplin, pengumpulan, penganalisisan, pensintesisan informasi dan data dari berbagai sumber (Nur, $2001: 1$ ).

. Sesuai dengan mata pelajaran PKn yang bersifat nyata maka guru dapat menggunakan pendekatan Contextual Teaching and Learning (CTL) untuk meningkatkan hasil belajar siswa.

Pembelajaran dengan pendekatan kontekstual lebih mengutamakan siswa untuk aktif, kreatif, dan kritis terhadap permasalahan yang disampaikan, lebih menekankan pada pengetahuan yang bermakna bagi siswa, berpusat pada siswa, siswa belajar tidak dengan menghafal tapi melakukan praktek, dalam pembelajaran peran guru hanya sebagai fasilitator yang memberikan arahan pada siswa, dan Hasil belajar belajar tidak hanya diukur dengan tes (Depdiknas, 2002 : 6).). Pembelajaran kooperatif dengan model pendekatan Contextual Teaching and Learning (CTL) mudah diterapkan pada semua mata pelajaran termasuk PKn. Dengan model pembelajaran pendekatan Contextual Teaching and Learning (CTL), siswa akan lebih aktif karena kelompok yang dibentuk adalah kelompok kecil dan masing-masing siswa mengamati perilaku temannya sendiri dan mencari sendiri alternatif pemecahan masalah yang dihadapi dari hasil pengamatannya.

Berdasarkan uraian di atas penulis, menjadi tertarik untuk mengadakan penelitian tindakan kelas (PTK) dengan judul "Meningkatkan Hasil Belajar Dengan Pendekatan Contextual Teaching and Learning (CTL) Mata Pelajaran PKn pada Siswa Kelas V SD Negeri 1 Jereweh Tahun Pelajaran 2015-2016"

\section{Metode Penelitian}

Penelitian ini dilaksanakan di SDN 1 Jereweh Kabupaten Sumbawa Barat siswa kelas V.Jumlah kelas V ada 26 siswa yang terdiri dari 11 siswa laki-laki dan 15 siswa perempuan. Jenis penelitian ini adalah penelitian tindakan kelas yang terdiri dari tahap Plan, Do, See and revition sebanyak 3 siklus. 
Teknik pengumpulan data yaitu observasi, dan tes. Teknik analisis data secara deksriptif kuantitatif berdasarkan rumus yang ada, yakni sebagai berikut:

1. Analisis Hasil Pengamatan/ Observasi

Data hasil observasi dianalisis dengan mendeksripsikan aktivitas yang terjadi selama pembelajaran berlangsung.

2. Analisis Hasil Belajar Siswa

Data hasil belajar diperoleh dari hasil belajar kognitif siswa setelah melakukan evaluasi pada setiap akhir siklus. Rentangan skor yang diperoleh yaitu 1-100, berdasarkan skor yang diperoleh siswa pada evaluasi akan dikatahui ketuntasan yang diperoleh siswa. Seorang siswa dikatakan telah tuntas belajar bila telah mencapai skor 65,00.

Untuk menghitung ketuntasan belajar siswa pada setiap Kompetensi Dasar digunakan rumus sebagai berikut.

$$
\text { Ketuntasan Belajar }=\frac{\sum \text { Skor yang diperoleh }}{\sum \text { Skor maksimal }} \times 100 \%
$$

Untuk menghitung persentase ketuntasan belajar klasikal digunakan rumus sebagai berikut.

$$
\text { Persentase Keberhasilan }=\frac{\sum \text { Siswa yang Tuntas }}{\sum \text { Siswa Satu Kelas }} \times 100 \%
$$

\section{Hasil Penelitian}

\section{A. Paparan dan Analisis Data Pada Siklus I}

\section{Hasil Belajar Siklus I}

Berdasarkan hasil evaluasi yang telah dilakukan pada siklus 1 menunjukkan ada 9 orang siswa dengan persentase 34,61 \% yang sudah tuntas dalam proses pembelajaran pada materi organisasi, 17 orang siswa yang belum tuntas dengan persentase $65,39 \%$, dan rata-rata nilai 58,88. Hal tersebut terlihat dari nilai-nilai siswa yang belum bisa mencapai KKM yaitu nilai 65.. Dikarenakan Ketuntasan klasikal siswa belum mencapai $85 \%$, sehingga perlu dilanjutkan ke siklus 2 .

Tabel 1Presentase nilai hasil evaluasi hasil belajar siklus I

\begin{tabular}{cccc}
\hline No & Rentang Nilai & $\begin{array}{c}\text { Jumlah } \\
\text { Siswa }\end{array}$ & Persentase \\
\hline 1 & $1-10$ & 0 & \\
\hline 2 & $11-20$ & 0 & \\
\hline 3 & $21-30$ & 0 & \\
\hline 4 & $31-40$ & 0 & \\
\hline 5 & $41-50$ & 8 & $31 \%$ \\
\hline 6 & $51-60$ & 9 & $35 \%$ \\
\hline 7 & $61-70$ & 6 & $23 \%$ \\
\hline 8 & $71-80$ & 3 & $11 \%$ \\
\hline
\end{tabular}




\begin{tabular}{ccc}
\hline 9 & $81-90$ & 0 \\
\hline 10 & $91-100$ & 0 \\
\hline
\end{tabular}

Berdasarkan tabel 1 terlihat hasil evaluasi pada siklus I, bahwa rentang nilai yang didapatkan oleh siswa adalah 41 - 80. Dengan presentase nilai tertinggi pada kisaran nilai 51 - 60 yaitu $35 \%$, disusul oleh kisaran nilai 41 - 50 yaitu $31 \%$, kemudian kisaran nilai 61 - 70 yaitu $23 \%$. Dan presentase terendah yang didapatkan pada kisaran nilai 71 - 80 dengan 11 $\%$.

\section{B. Paparan dan Analisis Data Siklus II Hasil Belajar Siswa Siklus II}

Berdasarkan hasil evaluasi yang telah dilakukan pada siklus 2 dalam proses pembelajaran pada materi orgaanisasi menunjukkan ada 18 orang siswa yang sudah tuntas dengan persentase $69,23 \%$, dan 8 orang siswa yang belum tuntas dengan persentase $30,77 \%$, dan rata-rata nilai yang di diperoleh pada siklus 2 yaitu 68,88. Hal tersebut terlihat dari nilai-nilai siswa yang belum bisa mencapai KKM yaitu nilai 65. Dikarenakan Ketuntasan klasikal siswa belum mencapai $85 \%$, sehingga perlu dilanjutkan ke siklus 3

Tabel 2: Presentase nilai hasil evaluasi hasil belajar siklus II

\begin{tabular}{cccc}
\hline No & Rentang Nilai & $\begin{array}{c}\text { Jumlah } \\
\text { Siswa }\end{array}$ & Persentase \\
\hline 1 & $1-10$ & 0 & \\
\hline 2 & $11-20$ & 0 & \\
\hline 3 & $21-30$ & 0 & \\
\hline 4 & $31-40$ & 0 & \\
\hline 5 & $41-50$ & 0 & $31 \%$ \\
\hline 6 & $51-60$ & 8 & $35 \%$ \\
\hline 7 & $61-70$ & 9 & $23 \%$ \\
\hline 8 & $71-80$ & 6 & $11 \%$ \\
\hline 9 & $81-90$ & 3 & \\
\hline 10 & $91-100$ & 0 & \\
\hline
\end{tabular}

Berdasarkan tabel 2 terlihat hasil evaluasi pada siklus 2, bahwa rentang nilai yang didapatkan oleh siswa adalah 51 - 90. Dengan presentase nilai tertinggi pada kisaran nilai 61 - 70 yaitu $35 \%$, dan disusul oleh kisaran nilai 51 - 60 yaitu $31 \%$, kemudian kisaran nilai 71 - 80 yaitu 23 $\%$. Dan presentase terendah yang didapatkan pada kisaran nilai 81 - 90 dengan $11 \%$.

\section{Paparan dan Analisis Data Siklus III Hasil Belajar Siswa Siklus III}

Berdasarkan hasil evaluasi yang telah dilakukan pada siklus 2 dalam proses pembelajaran pada materi organisasi menunjukkan semua siswa sudah mencapai nilai KKM yang artinya semua siswa pada siklus III sudah 
tuntas dalam proses pembelajaran pada dengan rata-rata nilai 78,88, sehingga tidak perlu dilanjutkan ke siklus selanjutnya.

Tabel 3: Presentase nilai hasil evaluasi hasil belajar siklus III

\begin{tabular}{cccc}
\hline No & Rentang Nilai & $\begin{array}{c}\text { Jumlah } \\
\text { Siswa }\end{array}$ & Persentase \\
\hline 1 & $1-10$ & 0 & \\
\hline 2 & $11-20$ & 0 & \\
\hline 3 & $21-30$ & 0 & \\
\hline 4 & $31-40$ & 0 & \\
\hline 5 & $41-50$ & 0 & \\
\hline 6 & $51-60$ & 0 & \\
\hline 7 & $61-70$ & 8 & $31 \%$ \\
\hline 8 & $71-80$ & 9 & $35 \%$ \\
\hline 9 & $81-90$ & 6 & $23 \%$ \\
\hline 10 & $91-100$ & 3 & $11 \%$ \\
\hline
\end{tabular}

Berdasarkan tabel 3 terlihat hasil evaluasi pada siklus III, bahwa rentang nilai yang didapatkan oleh siswa adalah 71 - 100. Dengan presentase nilai terbanyak pada kisaran nilai 71 - 80 yaitu sebanyak $35 \%$. Kemudian berikutnya kisaran nilai 61 - 70 yakni $31 \%$. Berikutnya kisaran nilai 81 - 90 yakni $23 \%$ Dan presentase terendah yang didapatkan pada kisaran nilai 91 - 100 yaitu $11 \%$

\section{Pembahasan}

Tujuan proses belajar mengajar secara ideal adalah agar bahan yang dipelajari dapat dikuasai sepenuhnya oleh siswa, hal itu yang disebut dengan "mastery learning" atau belajar tuntas, artinya siswa mampu melakukan penguasaan penuh terhadap materi pelajaran yang dipelajari. Peningkatan hasil belajar yang terjadi pada siklus III sehingga ketuntasan belajar secara klasikal dapat tercapai dipengaruhi oleh beberapa hal antara lain: (1) sebagian besar siswa sudah dapat memusatkan perhatian atau memperhatikan ketika ada temannya menjawab pertanyaan yang ada di LKS, (2) siswa memusatkan perhatiannya dalam mengerjakan LKS dan mengerjakannya dengan sebaik-baiknya, (3) siswa terlihat siap ketika menghadapi tes, karena sebelum diadakan tes mereka diberikan waktu utnuk belajar terlebih dahulu, (4) siswa sudah mampu mengolah informasi yang didapatkan dari pengamatan, dan (5) siswa mulai terbiasa dengan pembelajaran menggunakan Pendekatan Contextual Teaching and Learning (CTL).

Beberapa alasan mengapa Pendekatan Contextual Teaching and Learning (CTL) dapat meningkatkan hasil belajar diantaranya adalah 1) Pendekatan Contextual Teaching and Learning (CTL) menyediakan waktu berpikir untuk meningkatkan kualitas respon siswa, 2) Pendekatan Contextual Teaching and Learning (CTL) dapat meningkatkan kemampuan siswa dalam mengingat suatu informasi, 3) siswa menjadi lebih aktif dalam 
berpikir mengenai konsep dalam mata pelajaran, 4) siswa lebih memahami konsep topik pelajaran selama diskusi, dan 5) tidak ada siswa yang tidak bekerja untuk mengejakan LKS karena kelompoknya merupakan kelompok kecil yang beranggotakan terdiri dari 2 - 4 orang siswa.

\section{Simpulan}

Berdasarkan hasil dan pembahasan di atas maka dapat diambil kesimpulan bahwa penerapan Pendekatan Contextual Teaching and Learning (CTL) dapat meningkatkan hasil belajar siswa yang terlihat dari nilai ratarata pada saat siklus 1 rata-rata nilai 58,88 kemudian meningkat menjadi 68,88 pada siklus 2 dan 78,88 pada siklus 3, sedangkan ketuntasan maksimal yang tuntas meningkat 34,62 \% dari siklus 1 ke siklus 2, dan dari siklus 2 ke siklus 3 sebanyak $30,77 \%$.

\section{Daftar Rujukan}

Arikunto, 1997. Prossedur Penelitian: Suatu Pendekatan Praktik. Jakarta: Asdi Mahasatya.

Arikunto, Suharsimi. 2002. Dasar-Dasar Evaluasi Pendidikan.Jakarta: Rineka Cipta.

2007. Penelitian Tindakan Kelas.Jakarta : Remaja Rosdakarya.

Adji, Wahyu,dkk.2007.PKn SMP/MAjilid 3.Jakarta ; Erlangga.

Depdiknas. 2006. Kurikulum Tingkat Satuan Pendidikan, Mata Pelajaran IPA SD. Jakarta: Depdiknas.

Depdiknas, 2004. Kurikulum 2004 SD. Pedoman Khusus Pengembangan Silabus dan Penelitian Sains. Depdiknas. Jakarta..

Depdiknas, 2008. Kurikulum Tingkat Satuan Pendidikan Sekolah Dasar. Model Silabus Kelas IV. BSNP. Depdiknas. Jakarta.

Ibrahim, M. 2003. Pengembangan Perangkat Pembelajaran. Jakarta: Depdiknas

Ibrahim, M. 2006. Asesmen Berkelanjutan, Seri Pembelajaran Inovatif. Surabaya:Unesa University Press.

Gina, L. 2008. Acitive Learning, Increasing Flow In The Classroom. Pat Hollingsworth: Norwalk.

Mulyasa, E. 2006. Kurikulum Tingkat Satuan Pendidikan. Bandung: Rosdakarya.

Nur, M. 2002. Psikologi Pendidikan Fondasi untuk Pengajaran. Surabaya: Unesa.

Nur, M. 2001. Contectual Teaching and Learning, Surabaya:Unesa University Press.

Sardiman, AM. 2001. Interaksi dan Motivasi Belajar Mengajar. Jakarta: Grafindo Persada.

Sudjana, N dan Ibrahim. 2001. Penelitian dan Penilaian Pendidikan. Bandung: Sinar Baru AlgesindoDepartemen Pendidikan dan Kebudayaan. 1995. Kamus Besar Bahasa Indonesia. Jakrta: Balai Pustaka.

Suprijono, Agus. 2016 Cooperative Learning Teori dan Aplikasi Paikem.

Surabaya: Pustaka Pelajar. 